\title{
Sedimentation in an artificial lake - Lake Matahina, Bay of Plenty
}

\author{
CHRISTOPHER J. PHILLIPS* \\ CAMPBELL S. NELSON \\ Department of Earth Sciences \\ University of Waikato \\ Private Bag \\ Hamilton, New Zealand
}

\begin{abstract}
Lake Matahina, an $8 \mathrm{~km}$ long hydroelectric storage reservoir, is a small $\left(2.5 \mathrm{~km}^{2}\right), 50 \mathrm{~m}$ deep, warm monomictic, gorge-type lake whose internal circulation is controlled by the inflowing Rangitaiki River which drains a greywacke and acid volcanic catchment. Three major proximal to distal subenvironments are defined for the lake on the basis of surficial sediment character and dominant depositional process: (a) fluvial-glassy, quartzofeldspathic, and lithic gravel-sand mixtures deposited from contact and saltation loads in less than $3 \mathrm{~m}$ depth; (b) (pro-)deltaic-quartzofeldspathic and glassy sand-silt mixtures deposited from graded and uniform suspension loads in 3-20 m depth; and (c) basinal-diatomaceous, argillaceous, and glassy siltclay mixtures deposited from uniform and pelagic suspension loads in $20-50 \mathrm{~m}$ depth. The delta face has been prograding into the lake at a rate of 35-40 $\mathrm{m} /$ year and vertical accretion rates in pro-delta areas are $15-20 \mathrm{~cm} /$ year. Basinal deposits are fed mainly from river plume dispersion involving overflows, interflows, and underflows, and by pelagic settling, and sedimentation rates behind the dam have averaged about $2 \mathrm{~cm} /$ year. Occasional fine sand layers in muds of basinal cores attest to density currents or underflows generated during river flooding flowing the length of the lake along a sublacustrine channel marking the position of the now submerged channel of the Rangitaiki River.
\end{abstract}

Keywords Lake Matahina; lacustrine environments; lacustrine sediments; lacustrine sedimentation; sedimentation rates; hydro-electric storage lakes.

Received 29 May 1981; revised 4 September 1981

*Present address: N.Z. Forest Service, P.O. Box 944, Gisborne, New Zealand

\section{INTRODUCTION}

Lake Matahina ( $38^{\circ} 10^{\prime} \mathrm{S}, 176^{\circ} 50^{\prime} \mathrm{E}$ ), a hydro-electric storage lake, is situated on the Rangitaiki River, 50 $\mathrm{km}$ due east of Rotorua (Fig. 1). The Rangitaiki River rises in the Taupo pumice country and flows north into the Bay of Plenty, being joined by streams draining the ignimbritic Kaingaroa Plateau to the west and the Wheao and Whirinaki Rivers which originate in the steep greywacke ranges to the east above the lake. The Ministry of Energy (Electricity) (MOE) Matahina scheme, completed in 1966, comprises a $70 \mathrm{MW}$ power station and an embankment dam behind which the Rangitaiki River has backed up $8 \mathrm{~km}$ through a narrow ignimbrite gorge. The lake occupies $2.5 \mathrm{~km}^{2}$ and has an upstream catchment of $2844 \mathrm{~km}^{2}$ which ranges in altitude from 150 to $1300 \mathrm{~m}$.

Three major rock groups occur in the Rangitaiki River catchment (Fig. 1).

1. Permian to Lower Cretaceous banded argillites and alternating siltstones and greywacke sandstones of the Ikawhenua and Urewera Ranges.

2. Pliocene and Pleistocene acid volcanics dominated by the Te Whaiti, Rangitaiki, Matahina, and Kaingaroa Ignimbrites. Late Quaternary tephras mantle the area (Healy 1964) and, except for the A.D. 1886 basaltic Tarawera Lapilli, are of rhyolitic composition.

3. Late Pleistocene and Recent fluvial gravels, sands, and peats occupy the major depressions (Galatea and Waiohau Basins) and include conspicuous deposits of A.D. 130 Taupo Pumice Alluvium.

From MOE concern at the amount of sediment thought to have accumulated behind Matahina Dam since 1966 there existed a need for information on how much sediment was being deposited in the lake, how it was deposited, and what its characteristics were. Such information would provide a baseline against which future lake sedimentation data : ould be compared. Specific aims of this study were to establish the texture and composition of the surficial and sub -bottom lake sediments; to obtain information on lake water characteristics; and to establish whether or not density currents are important as a sediment transporting agent within the lake. Secondary aims were to determine the average rates 
of sedimentation in the lake and to develop a sedimentation model for Lake Matahina.

\section{METHODS}

Water depths were measured with a Marlin DIR 60 echo-sounder, and lead-line soundings were undertaken behind the dam face and in the delta growth area to obtain more detailed information on depths and rates of sediment accumulation. Forty-four surficial bottom sediment samples were collected with a 5 L capacity Ekman-Berge dredge, and 33 sediment cores ( $4 \mathrm{~cm}$ diameter) were obtained with an Alpine 202 piston corer with a $3 \mathrm{~m}$ coring barrel (Fig. 2). Sixteen gauging stations were established during each of December 1978, May 1979, and September 1979 at 6 across-lake transects (Fig. 2), and in situ profiles were recorded for lake water temperature and conductivity (Model 33 S-C-T Yellow Springs meter), clarity (Secchi disc), and current speeds (Gurley meter). Water samples were collected with a Nansen reversing bottle at each station at surface, mid-depth, and near-bottom levels, and their $\mathrm{Eh}$ and $\mathrm{pH}$ were measured immediately.

Details of the laboratory procedures followed were described by Phillips (1980). Water samples ( $c$. $500 \mathrm{ml}$ ) were filtered through preweighed Millipore AA $0.8 \mu \mathrm{m}$ filters, and suspended sediment concentrations $(\mathrm{mg} / \mathrm{L})$ were related to discharge for sediment load evaluation. The texture of sediment samples was analysed by standard sieving, pipette, and hydrophotometer techniques (Folk 1968, Jordan et al. 1971), and grain-size statistics were calculated by computer (Kamp 1979). Sediment composition was investigated by several techniques, including optical and scanning electron microscopy, $X_{i}$-ray diffractometry (Carroll 1970, Nelson \& Cochrane 1970), and differential thermal analysis. (All raw laboratory data are available on request from the second author.)

\section{LAKE CHARACTERISTICS}

Lake Matahina is a gorge-type reservoir with a maximum depth of $50 \mathrm{~m}$ (Fig. 2), a relative depth of $2.8 \%$, and an annually fluctuating water level of only $0.5-0.75 \mathrm{~m}$ (R. Shegedin, MOE, pers. comm.). Upper reaches of the lake are shallow $(1-4 \mathrm{~m})$, with a sinuous channel constricted by a narrow ignimbrite gorge (Fig. 3). As the gorge widens down lake, the depth increases to $15 \mathrm{~m}$ along a delta front, and to $40-50 \mathrm{~m}$ in the basin immediately behind the dam. A sublacustrine channel, formerly the subaerial channel of the Rangitaiki River, extends the full length of the lake, and sublacustrine levees are

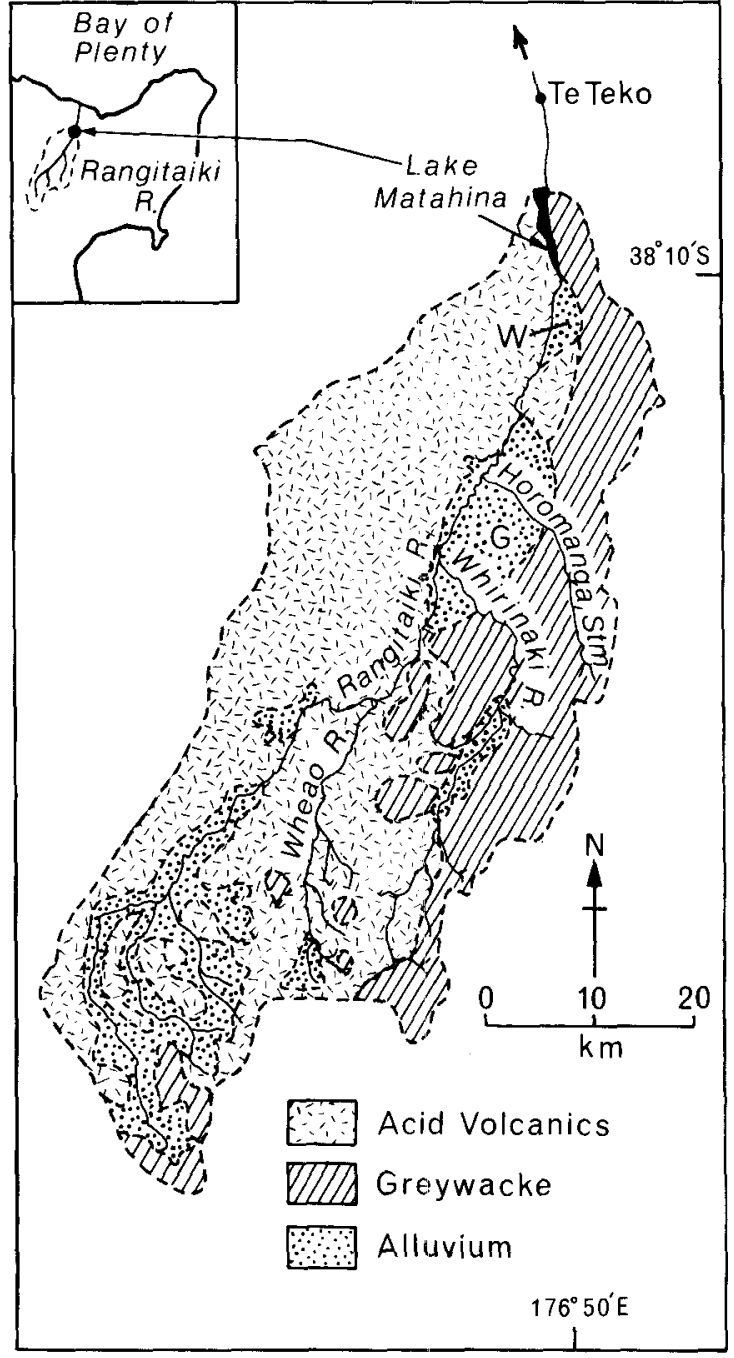

Fig. 1 Map of Lake Matahina showing generalised catchment geology (after Healy et al. 1964); W and G, Waiohau and Galatea Basins respectively.

evident. This channel has direct consequences for sediment transport, as discussed later.

Lake Matahina appears to be a warm monomictic lake (e.g., Jolly 1968). Temperature profiles (Fig. 4) show that the lake stratifies in summer and, although a winter profile was not obtained, it is likely that it overturns and becomes homothermous for at least part of this season.

Water movement within the narrow, elongate, stratified lake basin is influenced mainly by the inflowing Rangitaiki River (mean discharge at $\mathrm{Te}$ Teko is $c .74 \mathrm{~m}^{3} / \mathrm{s}$ ). Bulk residence time for lake water (lake volume/river flow) varies from about 21 
Fig. 2 Bathymetry, subenvironments, and gauging and sample locations in Lake Matahina.

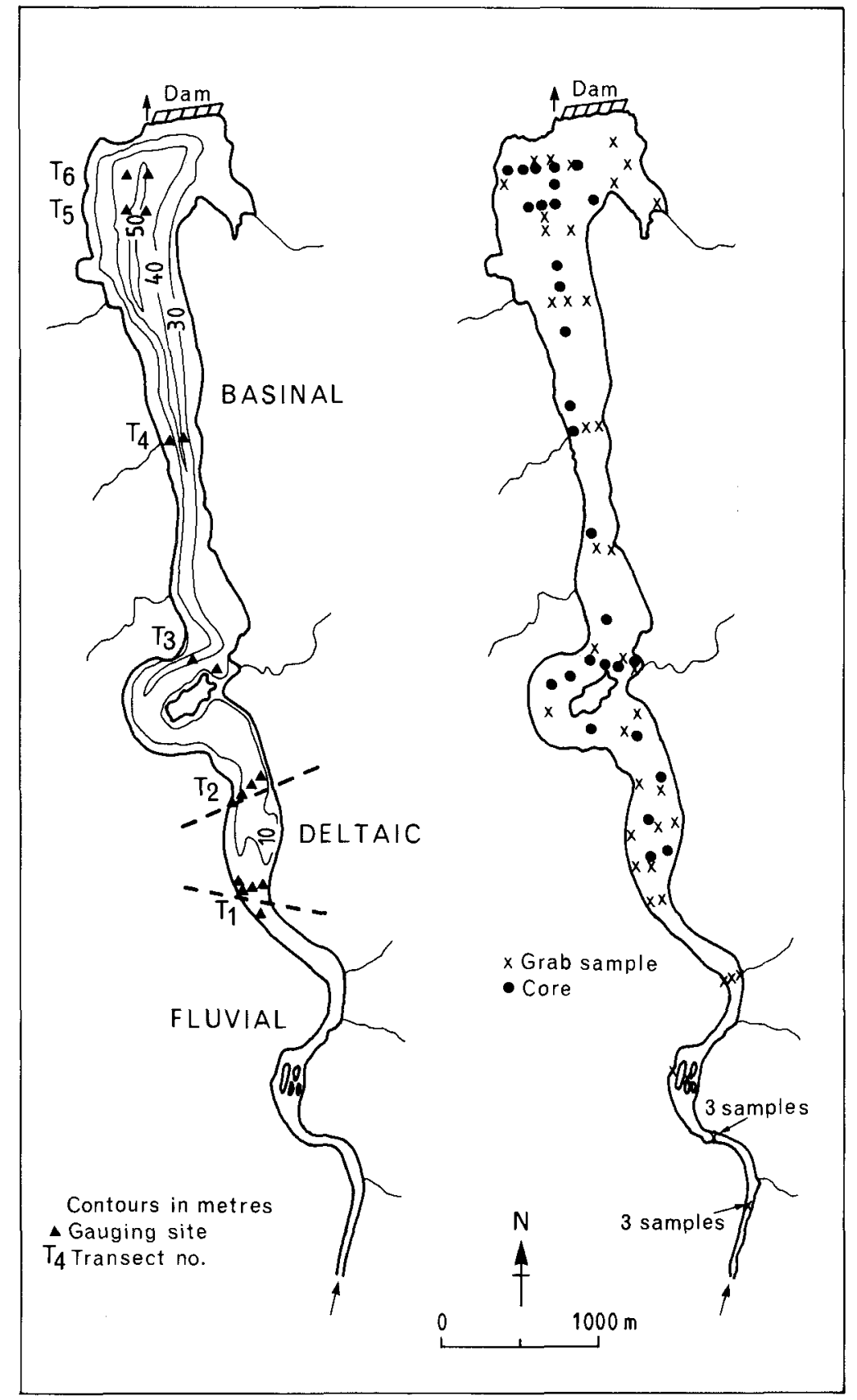

days in autumn (mean monthly low flows) to 12 days during spring (mean monthly peak flows). Wind probably plays only a minor role in lake circulation patterns as the surface area and width of the lake are small, and the prevailing southwesterlies blow at an angle to the long axis of the lake. Down-lake winds occur in winter and are responsible for near frostfree conditions at Matahina village, and up-lake breezes occur occasionally in summer, but little wave action results (R. Shegedin, pers. comm.). 


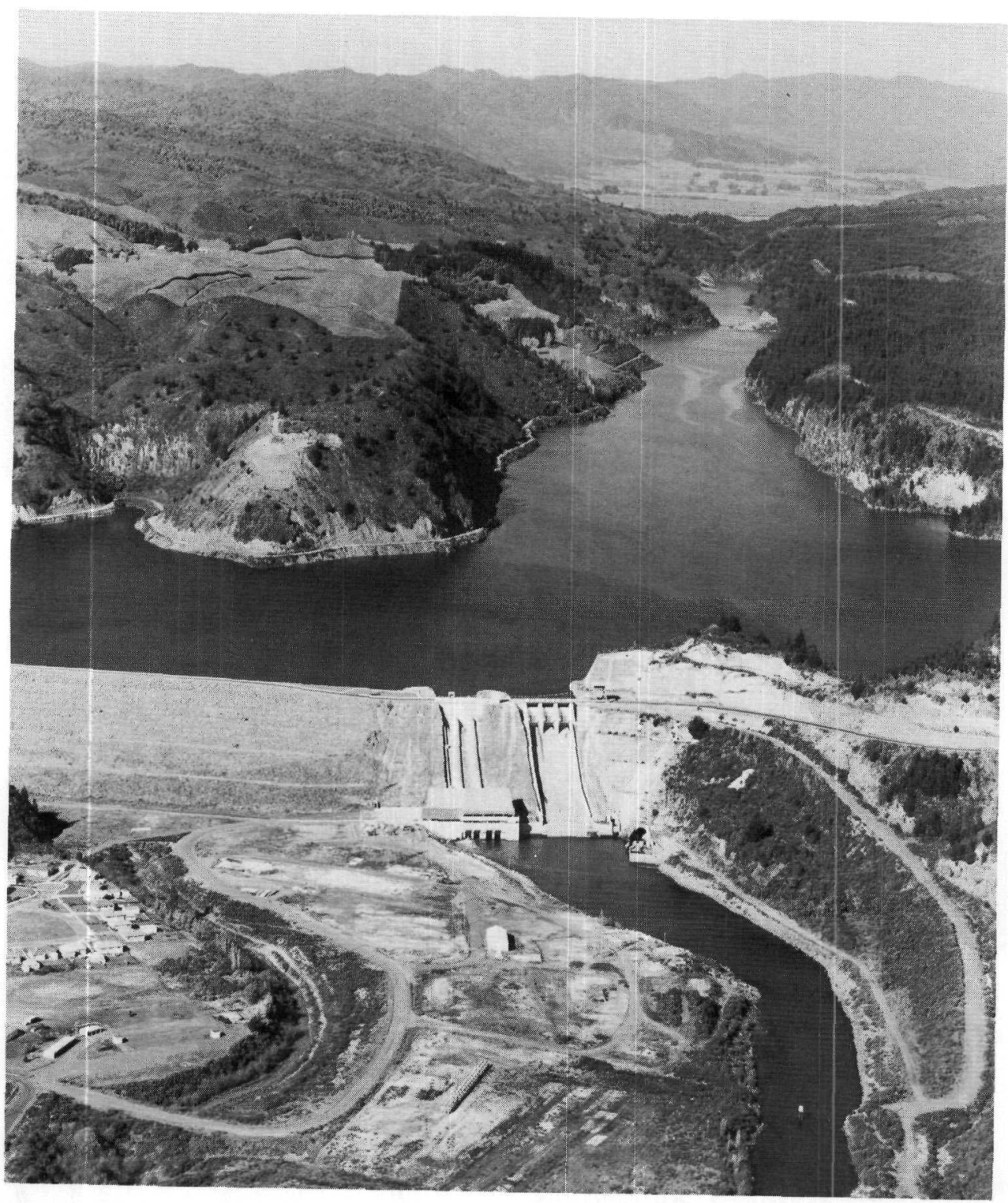

Fig. 3 Oblique aerial photograph (May 1970) looking south to Waiohau Basin showing gorge-like morphology of Lake Matahina behind dam face. Mainly greywackes of northern Ikawhenua Ranges on left and plateau formed on Matahina Ignimbrite extending away to right. (Photograph supplied by Aerial
Surveys Ltd, Nelson.)

Seasonal depth distributions of temperature, $\mathrm{pH}$, and conductivity are illustrated in Fig. 4. $\mathrm{pH}$ values ranged from 6.5 to 9.0 , and are thus considered normal (Hutchinson 1957). The $\mathrm{pH}$ curve for December 1978 (Fig. 4) shows a marked increase in the surface waters, possibly due to the photosynthetic utilisation of $\mathrm{CO}_{2}$, and a sharp drop in $\mathrm{pH}$ to 6.5 at $35 \mathrm{~m}$ depth due to the respiratory generation of
$\mathrm{CO}_{2}$ in the tropholytic zone and sediments. Profiles for the other sampling times show similar trends, but to a lesser degree.

The concentration of dissolved ions, expressed as conductivity, is low near the surface and generally increases with depth to a maximum at the sedimentwater interface. This is probably almost entirely due to the decomposition of organic remains and the 

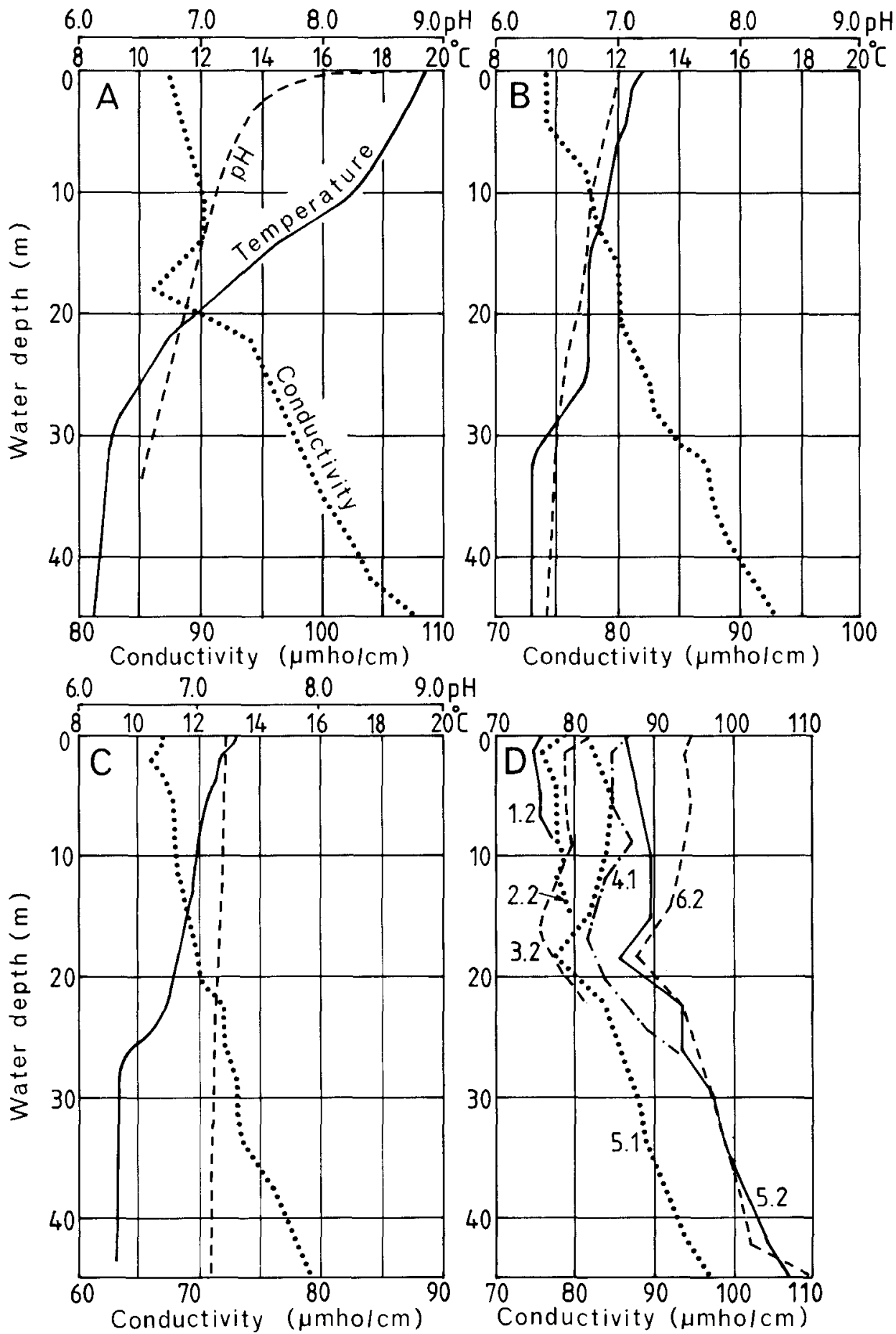

Fig. 4 Seasonal depth distributions of temperature, $\mathrm{pH}$, and conductivity in Lake Matahina: A-C, profiles taken $500 \mathrm{~m}$ up lake from dam outlet; A, 2 Dec 1978; B, 5 May 1979; C, 18 Sep 1979; D gives conductivity profiles only at various gauging stations (Transects 1-5, see Fig. 2) on 2 Dec 1978; note consistent kink in profiles from 15 to $18 \mathrm{~m}$ depth. 
subsequent release of ions. Eh values of all water samples ranged from 340 to $480 \mathrm{mV}$, indicative of non-stagnant conditions.

Lake waters are discoloured by river-borne humic materials leached from catchment soils, and Secchi depths are only 1-2 $\mathrm{m}$ year round. Light penetration in Lake Matahina closely resembles that in other New Zealand hydrolakes (Magadza 1973), but is generally much lower than in the surrounding natural lakes of the Rotorua region (Green 1975).

Suspended sediment concentrations within the main body of the lake are typically low (mainly $<20$ $\mathrm{mg} / \mathrm{L}$ ) compared with incoming river water $(>100$ $\mathrm{mg} / \mathrm{L}$ ), and increase significantly only during periods of high river discharge. Suspended sediment flux rates for the 3 sampling months have been calculated following the procedure of Hopkins (1978), and are summarised in Table 1. If the load at Transect 1 approximates the total available, then from 66 to $97 \%$ of the suspended sediment has been deposited above Transect 3 (Fig. 2). By the time water reaches the dam, from 71 to $98 \%$ of the load has been deposited. The data of Table 1 also suggest that a discharge exceeding about $100 \mathrm{~m}^{3} / \mathrm{s}$ has sufficient energy to transport and keep suspended a far greater proportion of its suspended load. Callander \& Duder (1979) considered that the trap efficiency of Lake Matahina is $100 \%$ for inflowing bed load material and about $64 \%$ for suspended sediment load.

Depending on the density difference between river and lake waters, river water entering a lake will, if physical mixing is minimal, continue moving as an overflow, interflow, or underflow current (Wetzel 1975). Flood discharges continuing as density currents have been reported for several lakes (e.g., Gould 1960, Brodie \& Irwin 1970, Lambert \& Lüthi 1977). In the ideal interflow or underflow model, water sinks to the bottom of a reservoir at the plunge line, which becomes a line of stagnation due to the setting up of a slow recirculating surface flow. Collection of floating debris and differences in turbidity of inflow and reservoir water make the plunge line visibly distinct, as was observed in Lake Matahina during December 1978. Increased flow, cooler water $\left(17^{\circ} \mathrm{C}\right)$, and a higher suspended sediment concentration (500 $\mathrm{mg} / \mathrm{L}$ ) after heavy rain resulted in the river water plunging beneath warmer $\left(20^{\circ} \mathrm{C}\right)$, less turbid $(2-5$ $\mathrm{mg} / \mathrm{L}$ ) lake water and moving as an interflow in the region of the thermocline. Evidence of down-lake continuity of the interflow is suggested by the December 1978 conductivity profiles (Fig. 4) and by the general relationships between current speed, suspended sediment concentrations, temperature, and conductivity for that period (Fig. 5). The absence of temperature kinks in the region of the
Table 1 Suspended sediment flux at Lake Matahina for 3 sampling periods. $q$, river or lake discharge $\left(\mathrm{m}^{3} / \mathrm{s}\right) ; \mathrm{s}$, mean suspended sediment concentration (ppm); $G s$, suspended sediment discharge ( $t /$ day) calculated using the formula of Hopkins (1978); gauging transects located on Fig. 2.

\begin{tabular}{lcccc}
\hline Transect & Parameter & $\begin{array}{c}2 \text { Dec } \\
1978\end{array}$ & $\begin{array}{c}5 \text { May } \\
1979\end{array}$ & $\begin{array}{c}18 \text { Sep } \\
1979\end{array}$ \\
\hline T1 & $q$ & 52.5 & 49.8 & 110.5 \\
& $s$ & 136.5 & 47.5 & 33.4 \\
T3 & Gs & 1641 & 541 & 845 \\
& $q$ & 52.5 & 49.8 & 110.5 \\
& $s$ & 4.0 & 9.0 & 11.5 \\
\% dropped from & $T 1$ to $T 3$ & 97 & 81 & 66 \\
T6 & $q$ & 52.5 & 49.8 & 110.5 \\
& $s$ & 3.0 & 2.0 & 9.6 \\
& Gs & 36 & 23 & 244 \\
\% dropped from & $T 1$ to $T 6$ & 98 & 96 & 71 \\
\hline
\end{tabular}

thermocline in these profiles could be due either to a lack of detailed temperature measurements at this depth or to dissipation of heat from the interflow to the surrounding lake water. The small kink near the water surface in the September 1979 conductivity profile is thought to illustrate an overflow most probably induced by draw-off of water by the power station.

\section{SURFICIAL SEDIMENT TEXTURE}

Surficial sediments of Lake Matahina include a number of textural classes (Fig. 6), reflecting various subenvironments of deposition. Fig. 7 summarises their distribution. (Isopleth maps showing weight percent of sand, mud, silt, and clay sizes in Lake Matahina are available on request from the second author.) Sediment texture is broadly related to distance from the active river inflow, and 4 environmentally related textural groups can be recognised (Fig. 7).

1. Fluvial sediments which include sandy gravels and gravelly sands.

2. Deltaic sediments are generally silty sands, sandy silts, or silts.

3. Basinal sediments are almost entirely muds (subequal amounts of silt and clay), but may include silts.

4. Talus sediments are slightly gravelly muds or gravelly muds.

Fluvial sediments occur in channel, channel bar, and point bar deposits in upper reaches of the lake where river flow is constricted by the narrow ignimbrite gorge. They are typically poorly to moderately sorted sandy gravels or gravelly sands 


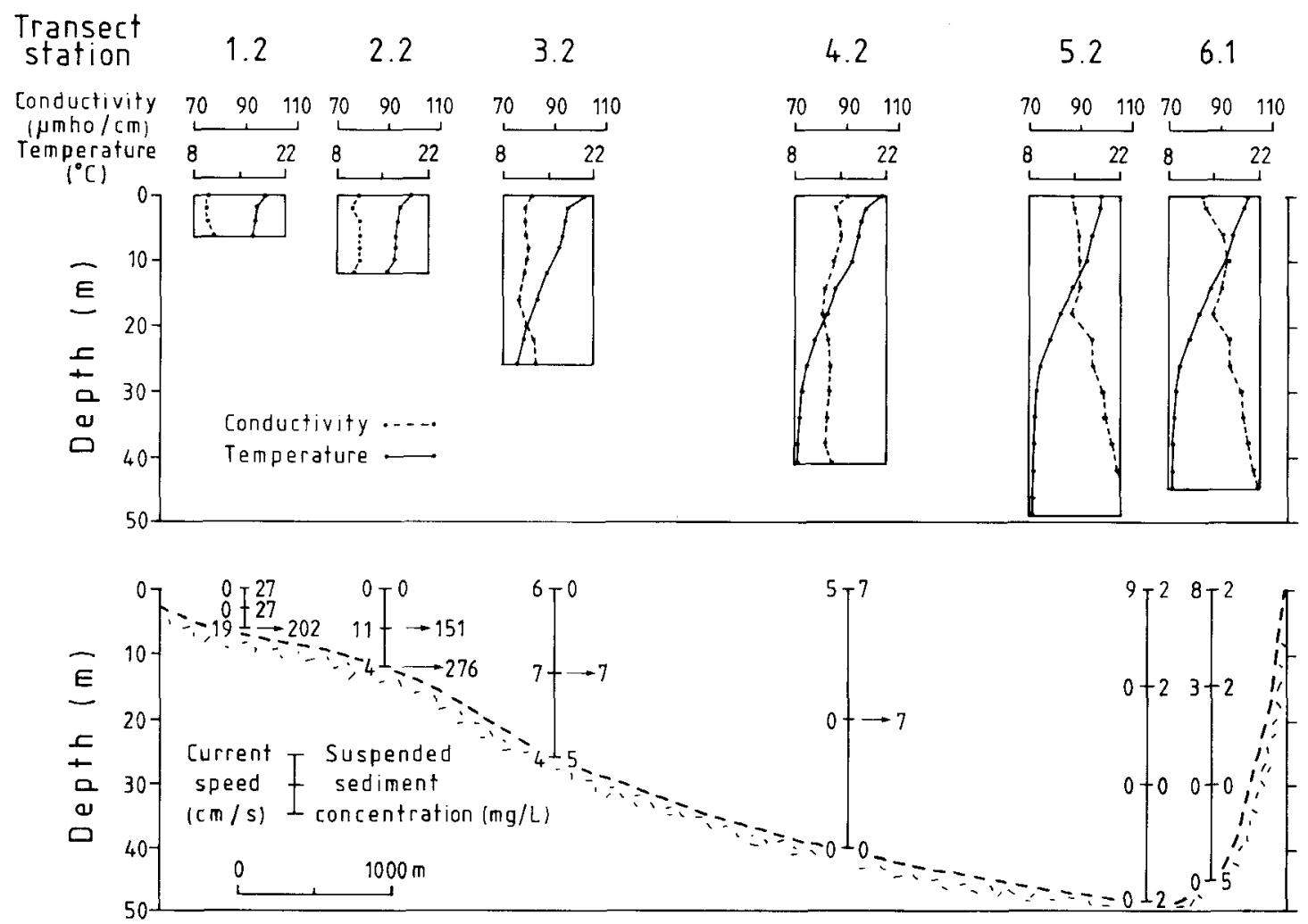

Fig. 5 Relationships between temperature, conductivity, current speed, and suspended sediment concentration of lake waters at 6 gauging transects (Fig. 2) in Lake Matahina, 2 Dec 1978; note evidence of an interflow in region of thermocline.

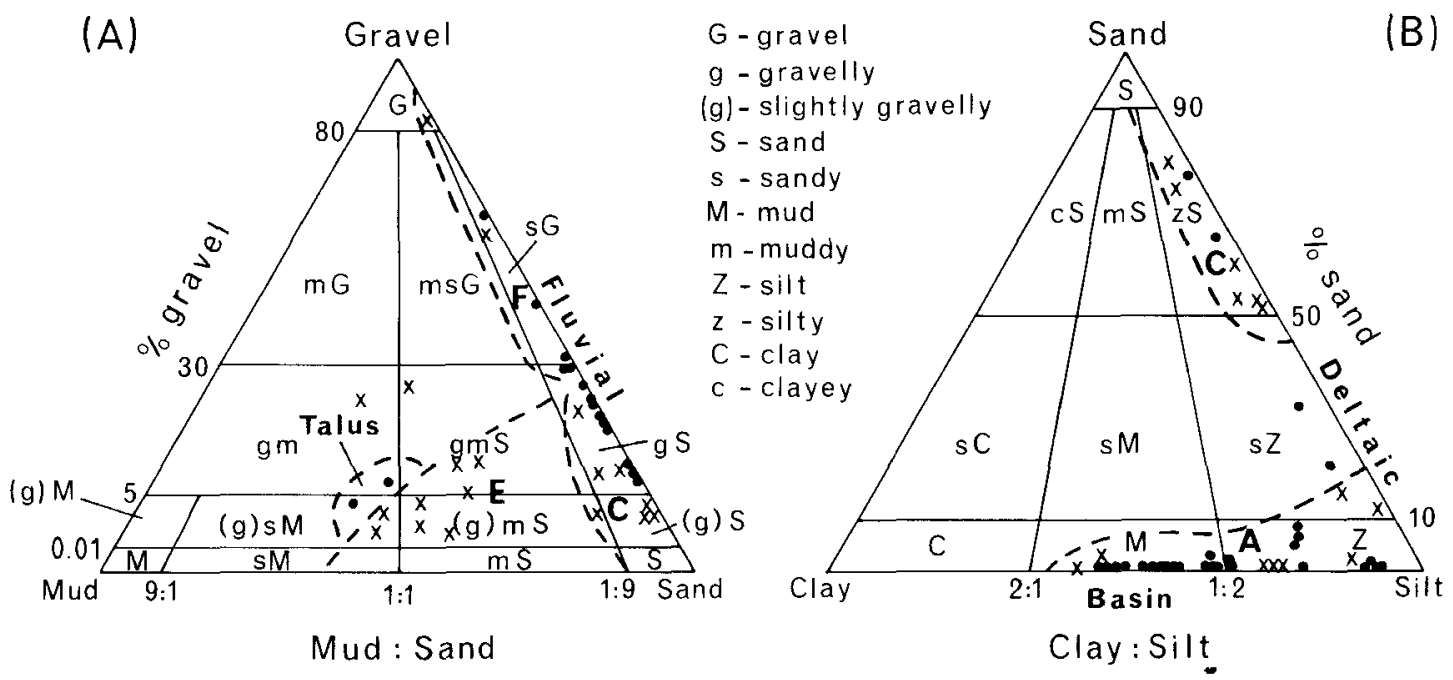

Fig. 6 Triangular textural plots (after Folk et al. 1970) of sediments from Lake Matahina. Dots represent surficial samples, those from each of the fluvial, deltaic, basin, and talus regions of lake tending to group in specific areas of plots, as indicated. Crosses are samples from cores, fields A, C, E, and F outlined by dashes encompassing sediments from inferred paleoenvironments defined in Table 2 \& Fig. 10. 
having fine-skewed to coarse-skewed distributions. Sediments are commonly bimodal or polymodal, the modes lying within the coarse or very coarse sand grade $(1$ to $-1 \phi)$. Textural characteristics reflect the river-dominated influence, especially the high current speeds $(20-100 \mathrm{~cm} / \mathrm{s})$ which prevent settling of fine sediment.

With increasing depth to over $3 \mathrm{~m}$ and widening of the gorge the current speeds drop below $20 \mathrm{~cm} / \mathrm{s}$ (av. $5 \mathrm{~cm} / \mathrm{s}$ ), and sediments are deposited as a delta. The sediments become increasingly silt-rich with depth, and are generally unimodal and poorly sorted. From top to bottom the deltaic sequence includes: (a) delta topset beds-predominantly sands (including sublacustrine channel deposits) which grade up-lake into fluvial gravelly sands; (b) delta foreslope beds-mainly muds which include in the subsurface several sand layers of underflow or slump origin; and (c) pro-delta beds-mainly muds with minor sandy intercalations.

The birds-foot delta typical of many lakes (Reineck \& Singh 1973) is modified significantly in Lake Matahina by the existence and maintenance of a sublacustrine channel, following the former Rangitaiki River channel, with associated sublacustrine levees composed of very fine sand and silt with intercalations of clay and plant debris (Fig. 8). The channel focuses sedimentation towards the west side of the delta, as illustrated by the down-lake tongue of sand from the delta face (Fig. 7). Because the lake is small, it is unlikely that the Coriolis deflection significantly influences this pattern of westward delta growth (cf. Pharo \& Carmack 1979).

No morphologic shelf occurs in Lake Matahina because of the bounding steep ignimbrite cliffs, both subaerial and sublacustrine, and true slope environments exist only locally. The area down-lake of the island is designated basinal. Beyond $20 \mathrm{~m}$ depth the bottom sediments show an increase in clay content at the expense of silt (Fig. 9), and they possess a wide range of sorting and skewness values. They are unimodal or bimodal, size modes occurring in the coarse silt $(4.0-4.5 \phi)$ and/or fine silt $(6.5-7.0 \phi)$ grades, the former comprising mainly terrigenous grains and the latter mainly diatom frustules. Consistent values of the clay to silt ratio (0.7-1.3) in muds throughout the lake suggest that currents are generally sufficiently strong both to transport siltsized material the length of the lake and to maintain fine clay in suspension. Sand-sized material is generally absent from the surficial basinal muds, but does occur as discrete layers in the sediment cores (see below).

Localised patches of sandy or gravelly muds occur in the basinal region in the vicinity of stream influents or in areas of contemporary or pre-lake talus slopes (Fig. 7).

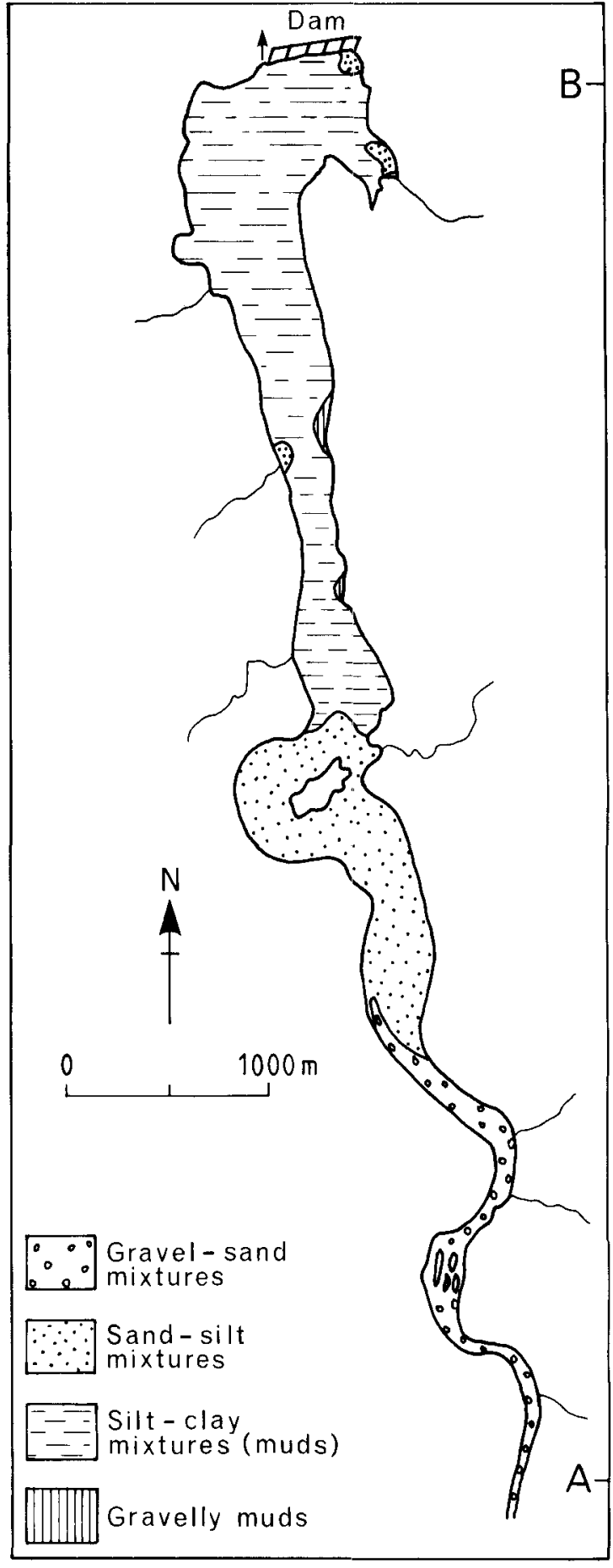

Fig. 7 Distribution of major surficial sediment textural types in Lake Matahina; $A$ and $B$ denote limits of profile in Fig. 9. 


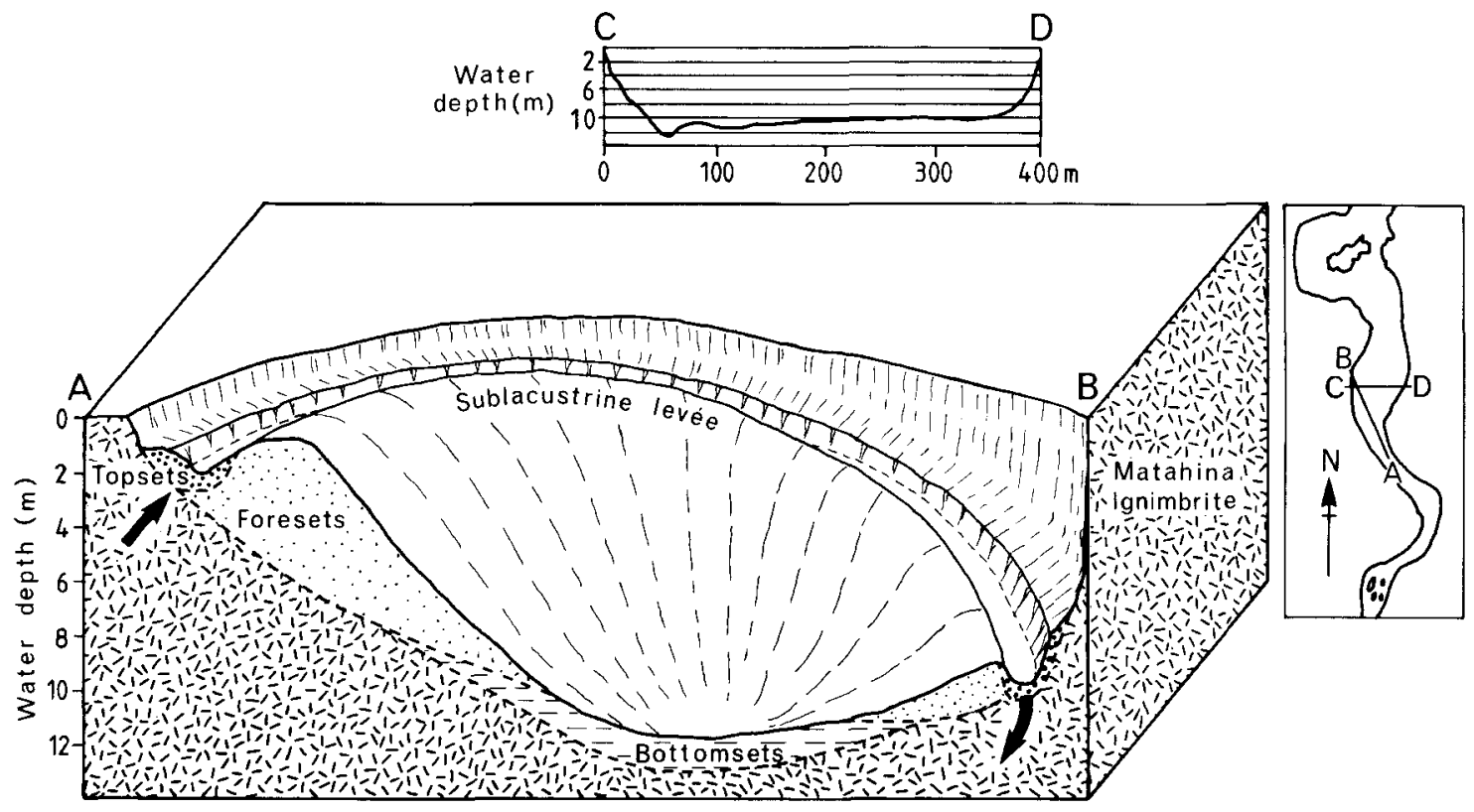

Fig. 8 Block diagram of delta area of Lake Matahina showing relationships between sedimentary deposits and lake morphology; arrows denote direction of water movement in sublacustrine channel.

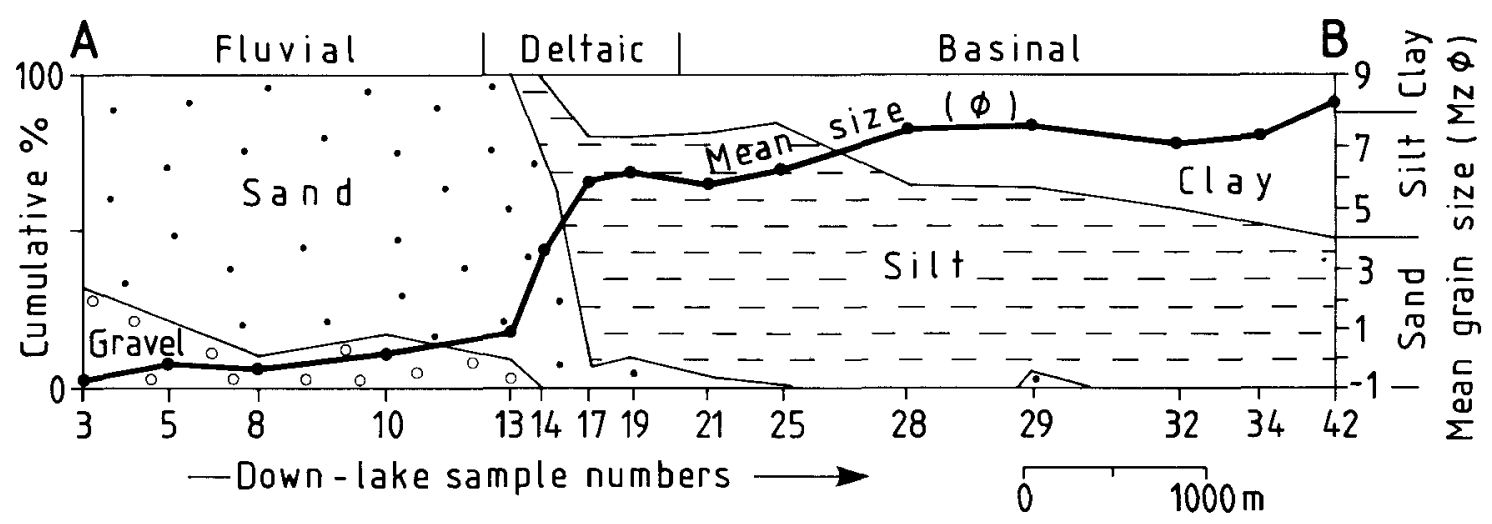

Fig. 9 Textural profile for Lake Matahina (A \& B located on Fig. 7) showing down-lake changes in contents of gravel, sand, silt, and clay in surficial sediments, and variations in their mean grain size (Mzф; Folk 1968).

\section{SURFICIAL SEDIMENT COMPOSITION}

Surficial sediments contain 5-15\% (av. 7\%) organic matter. Variations in bulk mineralogy mainly reflect sediment textures. Gravel material is dominantly pumice with less common greywacke, ignimbrite, and scoria clasts; sand grains are mainly glass shards with various quantities of pumice, quartz, feldspar (calcic-oligoclase \pm calcic-andesine $\gg$ orthoclase \pm sanidine), and occasional $\alpha$-cristobalite and heavy minerals (cummingtonite, hypersthene, titanomagnetite, hornblende, biotite, and augite); silt particles have a similar composition to the sand fraction, except that diatom frustules, including species of Cocconeis, Pinnularia, Rhopalodia, Cymbella, Navicula, Fragilaria, Gomphoneis, Melosira, and Nitzchia, appear in the finer silt (6$8 \phi)$ sizes; and the clay fraction comprises mainly glass fragments and diatomaceous silica with less common halloysite, allophane, kaolinite, and illite. 
Table 2 Sedimentary characteristics (see also Fig. 6) and inferred origins (see also Fig. 10) of the 6 lithotypes defined in cores from Lake Matahina.

\begin{tabular}{lll}
\hline Lithotype & \multicolumn{1}{c}{ General sedimentary features } & Interpretation \\
\hline A & $\begin{array}{l}\text { Massive dark-coloured muds, generally silt-rich and sand- } \\
\text { poor. Mainly unimodal, poorly sorted and fine-skewed } \\
\text { Bery poorly sorted, grey, gravelly muds comprising angular } \\
\text { ignimbrite clasts set in a matrix of crushed ignimbrite }\end{array}$ & Lacustrine deposits \\
C & $\begin{array}{l}\text { Generally poorly sorted, fining-upward sequences involving } \\
\text { pumiceous gravelly sands and glassy silty sands. Bimodal or } \\
\text { polymodal sizes }\end{array}$ & Fluvial bar deposits \\
D & $\begin{array}{l}\text { Poorly sorted, fine-skewed, muddy sands and silts with } \\
\text { conspicuous organic material }\end{array}$ & $\begin{array}{l}\text { Paleosols on } \\
\text { deposits }\end{array}$ \\
E & $\begin{array}{l}\text { Mainly alternating coarse and fine sediment couplets of } \\
\text { gravelly muddy sands and sand-mud mixtures. Poorly } \\
\text { sorted and bimodal sizes } \\
\text { Poorly sorted, fine-skewed, sandy gravels containing }\end{array}$ & $\begin{array}{l}\text { Fluvial flood - overbank } \\
\text { deposits }\end{array}$ \\
Folished greywacke pebbles & Fluvial channel deposits \\
\hline
\end{tabular}

The terrigenous mineralogy is consistent with derivation from both the catchment greywackes (mainly greywacke lithics, some quartz and plagioclase, orthoclase, kaolinite, and illite) and acid volcanics (mainly pumice and ignimbrite lithics, glass shards, quartz, plagioclase, sanidine, $\alpha$ cristobalite, heavy minerals, halloysite, and allophane), the latter provenance, and particularly the Late Quaternary tephra mantle or its reworked fluvial products (e.g., Taupo Pumice Alluvium), accounting for the bulk of the sediment presently entering the lake. The diatomaceous content of basinal muds increases with increasing distance down-lake of the delta, and frustules may form up to $10-20 \%$ of samples.

\section{SEDIMENT CORES AND SEDIMENTATION RATES}

The sediments in lake bottom cores were grouped into one of 6 lithotypes (A-F) on the basis of colour, texture, composition, and sedimentary structures (Table 2). Lithotype A corresponds to lacustrine sediments formed since dam construction, lithotype $B$ is dam workings, and lithotypes C-F are interpreted as products of different fluvial subenvironments formed before construction of the dam (Table 2 \& Fig. 10). The relationship between these lithotypes in the lake sediment cores is shown in Fig. 11.

Of special interest is the occurrence of up to 5 discrete sand layers or lenses in the otherwise sandfree muds of lithotype A. In pro-delta areas of the lake the sand layers are up to $2-3 \mathrm{~cm}$ thick, but in distal basinal cores thicknesses of only $2-3 \mathrm{~mm}$ are more typical. Moreover, the sand horizons are most obvious in cores collected in the vicinity of the sublacustrine channel. Good correlation of sand layers is possible between 7 of the basinal mud cores taken adjacent to the dam (Phillips 1980). The sand is of fine to medium grade and contains predominantly well sorted, subangular to subrounded grains of volcanic glass and minor amounts of quartz, lithic fragments, biotite, and hypersthene. Generally, both the upper and lower contacts of the sand lenses are sharp, although the upper contact is often texturally less distinct then the lower. Internal sedimentary structures are usually not obvious, possibly because of some disturbance during the opening of cores, but occasionally the sand layers exhibit normal grading. It is inferred that the sand layers were deposited by density currents or underflows arising from flooding of the Rangitaiki River. A possible correlation between known high discharge $\left(>100 \mathrm{~m}^{3} / \mathrm{s}\right)$ periods and sand layers in a core from behind the dam is shown in Fig. 12.

Callander \& Duder (1979) showed that most work in the Rangitaiki River is done by moderate, frequently occurring floods rather than by individual extreme events, and gave an annual sediment accumulation in Lake Matahina of 181500 tonnes. Accumulation rates based upon the thickness of deposited sediment in cores vary from $2 \mathrm{~cm} /$ year at the dam to over $17 \mathrm{~cm} /$ year at the delta face, and average $9.4 \mathrm{~cm} /$ year over the lake as a whole. Assuming this average accumulation rate and a lake floor area of $2.5 \mathrm{~km}^{2}$, then the volume of sediment deposited annually is $235000 \mathrm{~m}^{3}$. Callander \& Duder (1979) assumed a specific gravity of 1000 $\mathrm{kg} / \mathrm{m}^{3}$, but Phillips (1980) has shown that the density of Lake Matahina sediments ranges from about 1000 to $2100 \mathrm{~kg} / \mathrm{m}^{3}$. Thus we estimate a $30 \%$ increase in 
Fig. 10 Model of fluvial sedimentation (after Pettijohn 1975) used to interpret depositional paleoenvironments of lithotypes C-F in Lake Matahina sediment cores (see Table 2).
Fig: 11 Relationships bet-ween various lithotypes of Table 2 in sediment cores from Lake Matahina.
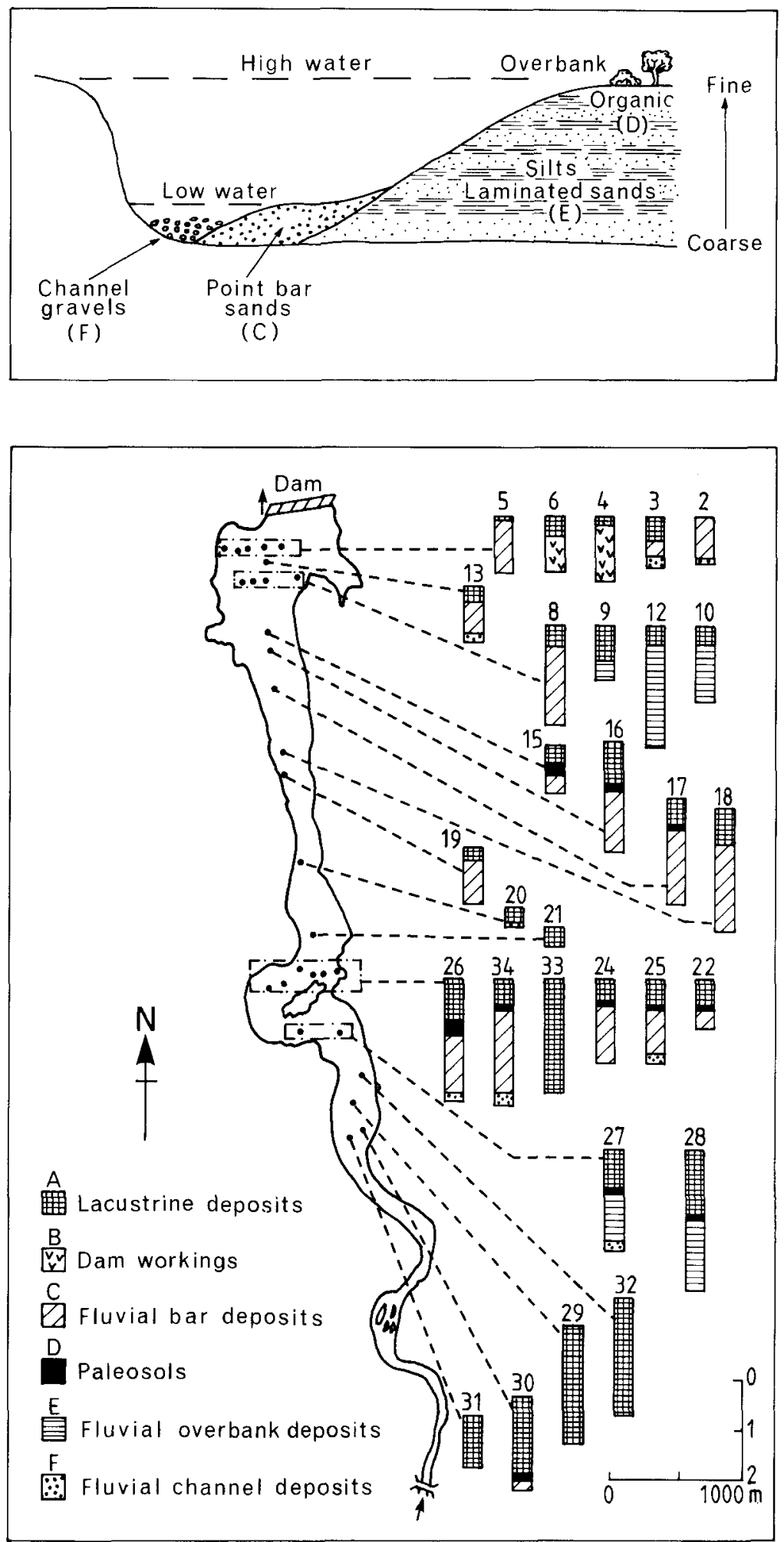
the volume of material deposited annually compared to Callander \& Duder's figure, although on a mass basis our yield is several hundred percent greater.

\section{SEDIMENTATION}

Several models of sedimentation for lacustrine environments have been proposed, both mathematical (e.g., Killworth \& Carmack 1977, Chen et al. 1978), and conceptual (e.g., Gould 1960, Pharo \& Carmack 1979). The morphologic, sedimentologic, and limited hydrologic data presented here are sufficient to derive a depositional model for Lake Matahina based on Pharo \& Carmack's (1979) model of sedimentation in Kamloops Lake, Canada, in which both the water and sediment budgets are dominated by input from a single river. The model incorporates 4 interdependent but distinct mechanisms: delta progradation, sediment density surges, river plume dispersion, and pelagic settling (Fig. 13).

Delta progradation occurs at the confluence of the fast-flowing Rangitaiki River water and the relatively quiet lake water where the sudden decrease in river velocity to less than $20 \mathrm{~cm} / \mathrm{s}$ causes rapid deposition of fluvial bed-load sediment on the delta platform and upper delta face. During maximum mean monthly river flows (JuneOctober) (I. G. Jowett, Ministry of Works \& Development, pers. comm.) especially active sedimentation of gravels and coarse and medium sands occurs, together with some interspersed silt and organic debris layers. The soundings of Callander \& Duder (1979), together with our own surveys, indicate that the delta front advanced down-lake at a rate of about $36 \mathrm{~m} /$ year between 1971 and 1975 , increasing to about $40 \mathrm{~m} /$ year from 1975 to 1979. However, now that the delta is emerging into the lake proper, it is anticipated that the delta progradation rates will slow as there is a much larger front to which sediment can be added.

Sediment density surges are short-lived phenomena resulting from disturbance of already deposited deltaic sediments to form high density turbulent flows (e.g., Brodie \& Irwin 1970). The density surges may be generated by localised delta slope failures associated with earth tremors, sediment overloading, delta-edge wave action and, perhaps most importantly, by sudden flooding of the surface and leading edge of the delta after periods of low lake levels. No direct evidence of delta face slumping was obtained, either visually or by soundings, but some of the thin, occasionally graded, sharp-based sand lenses in the lacustrine mud cores may have been deposited from such catastrophic density currents. Daily operation of the

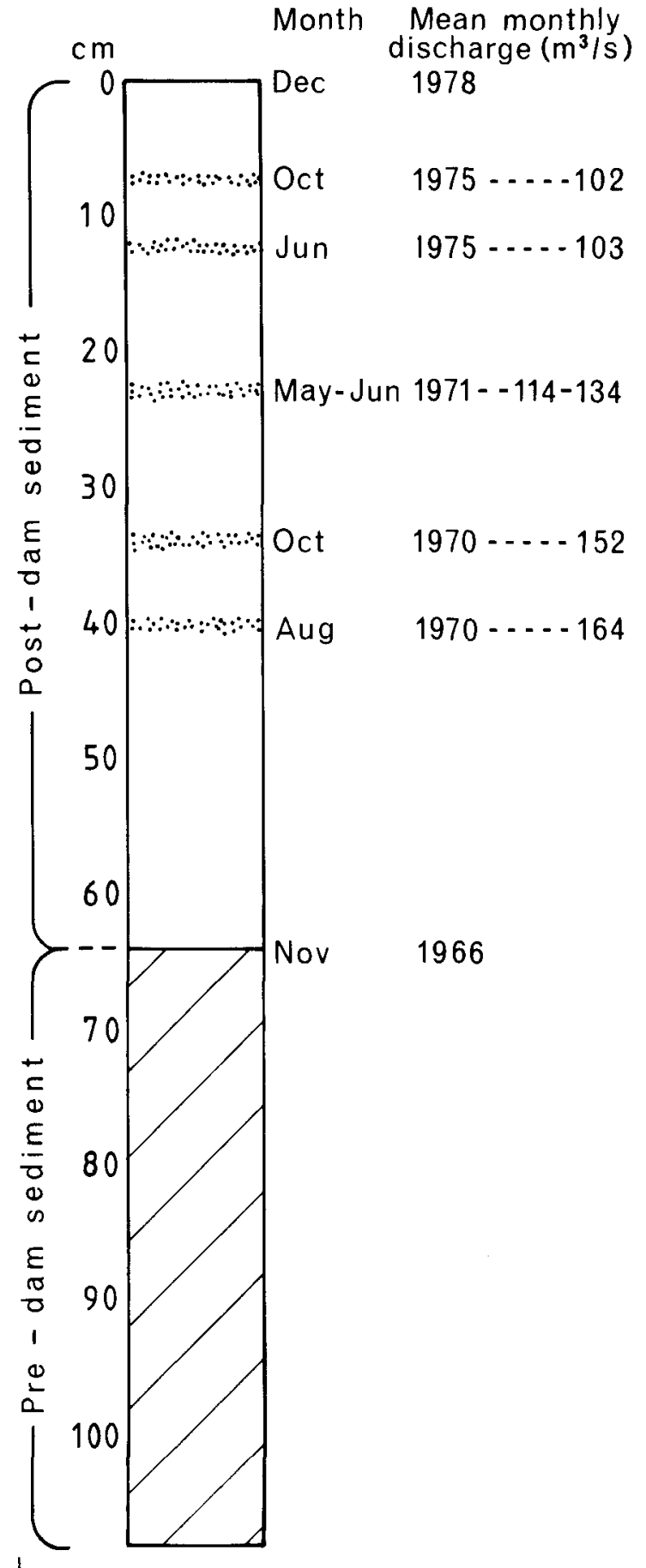

Fig. 12 Possible correlation between river or lake discharge (N.Z. Ministry of Works and Development 1978) and occurrence of sand layers in lacustrine muds of core 9 (see Fig. 11). 


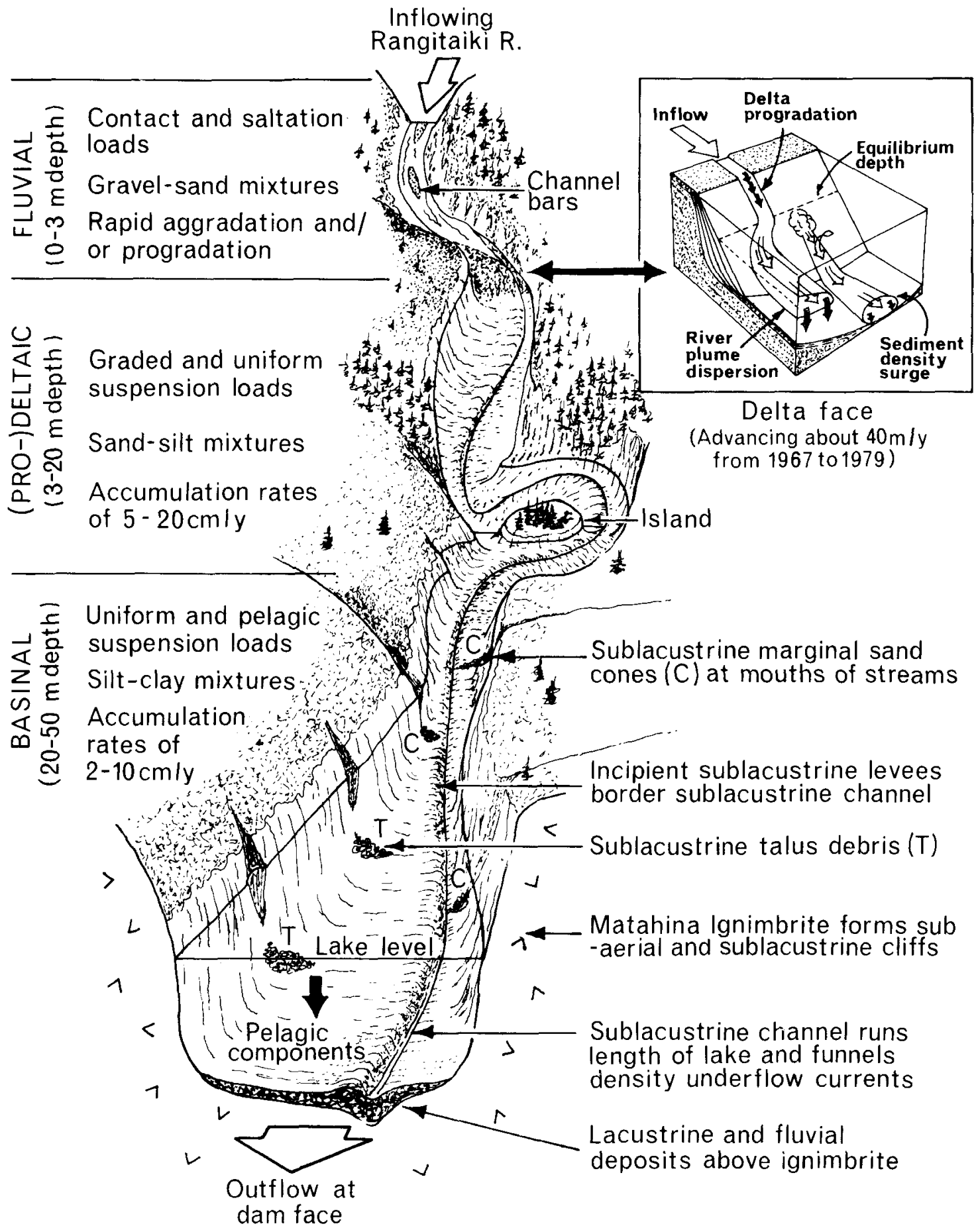

Fig. 13 Conceptual model of deposition for Lake Matahina; delta face (inset top right) adapted from Pharo \& Carmack (1979); open arrows denote fluid motion, black arrows sedimentation. 
Aniwhenua power scheme, $25 \mathrm{~km}$ up-river from lake Matahina, might well accelerate these kinds of processes.

River plume dispersion involves the transport and deposition of very fine sand to clay-sized sediment by a coherent plume of river water as it moves through the lake as a surface overflow, an interflow, or an underflow, depending upon the density of the inflowing water relative to that of lake water. Lake water characteristics, such as conductivity and suspended sediment distribution (Fig. 4 \& 5), provide evidence for the existence of such subsurface flow. Under average flow conditions the Rangitaiki River delivers in suspension mainly clay and fine silt-sized sediments, over $70 \%$ of which is usually deposited in the lake (Table 1). However, during flood discharges, high density underflows are probably important agents for distributing a proportion of coarser-grade sediments into the lake. Sedimentologic evidence for the confinement of riverine flow within the lake is expressed by the general gradient from coarser to finer sediment below the delta (Fig. 9) and by a tongue of coarse sediment which extends along the western shore away from the delta (Fig. 7), generally following the line of the former river course. It is suspected that the sand layers in pro-deltaic and basinal mud cores are mainly the products of major underflow events (Fig. 12). The sand layers are more numerous and generally thicker near the submerged channel of the Rangitaiki River, and it is presumed that this channel acts as a preferential path for the underflow or density currents.

Intra-lake biogenic components, mainly diatom frustules, may settle pelagically from quiet lake waters along with terrigenous fine silt and clay introduced initially into the lake by river plume dispersion. However, compared to the riverine terrigenous input, biogenic pelagic components are only minor sediment contributors at Lake Matahina, and reach maximum abundances of $10-20 \%$ in the more distal basinal mud deposits.

\section{Effects of damming the Rangitaiki River}

Since 1967 the Lake Matahina dam has acted as an effective barrier to the seaward movement of sediment by the Rangitaiki River (mean discharge $74 \mathrm{~m}^{3} / \mathrm{s}$ ). Pre-dam annual discharge figures for suspended and bed load sediment near the river mouth were about 201000 and $188000 \mathrm{t}$ respectively, but equivalent post-dam values have dropped to only 65000 and $10000 \mathrm{t}$ (T. R. Healy, University of Waikato, pers. comm.). As a result, the Rangitaiki River downstream of the dam has had to readjust its channel configuration by bank erosion and bottom scour to obtain equilibrium, coastal progradation of the Rangitaiki Plains has probably been reduced significantly from the 0.5 to $0.7 \mathrm{~m} /$ year suggested by Pullar \& Selby (1971), and it is possible that the trapping of all bed load and most $(>70 \%)$ suspended load sediment in the lake is a contributing factor to the observed erosional or unstable state of portions of the Bay of Plenty coastline in the vicinity of the Rangitaiki River mouth (Healy et al. 1977).

\section{CONCLUSIONS}

The texture and composition of surficial and subbottom sediments in Lake Matahina reflect the interactions between supply of sediment from 2 major source lithologies-greywackes in the east and, more importantly, acid volcanics of both flow (ignimbrites) and particularly air-fall (tephras) origin in the west-and the influence of the inflowing Rangitaiki River upon water circulation and sediment dispersion within the lake. Three major proximal to distal lacustrine subenvironments occur: fluvial, deltaic, and basinal. Fluvial sediments occur in the upper reaches of the lake in depths of less than $3 \mathrm{~m}$ and are lithic (pumice $>$ greywacke) dominated, gravel-sand mixtures deposited from bed load in ephemeral channel and bar deposits. Deltaic sediments accumulate where the lake suddenly deepens from 3 to $20 \mathrm{~m}$ and are mainly glass-dominated sand-silt mixtures deposited from graded and uniform suspension. Delta progradation has occurred at a rate of 33-40 m/year and delta morphology has been strongly influenced by the existence of a sublacustrine channel along the west side of the lake following the former course of the pre-dam Rangitaiki River channel. In pro-delta areas of the lake vertical accumulation rates are 15 $20 \mathrm{~cm} /$ year. Basinal sediments occur deeper than 20 $\mathrm{m}$ and are glassy-argillaceous (-diatomaceous) siltclay mixtures fed mainly by river plume dispersion of suspended sediment in overflows, interflows, and underflows. Sedimentation rates at the dam are about $2 \mathrm{~cm} /$ year. Fine sand layers in muds of basinal cores are probably deposited from density or underflow currents, generated during river flooding, flowing the length of the lake along the sublacustrine channel.

\section{ACKNOWLEDGMENTS}

We thank $\mathrm{Mr} \mathrm{R}$. Shegedin (Ministry of Energy Electricity) for his co-operation and assistance; Messrs $M$. Vennard, L. Gaylor, G. Steele, and P. Codlin (Department of Earth Sciences, University of Waikato) for assistance with field work; Dr C. Beltz (University of Waikato) for assistance with scanning electron microscopy and the identification of diatom species; and Drs J. Green (University of Waikato), A. Pearce (Forest Research 
Institute, Christchurch), and L. Carter (New Zealand Oceanographic Institute) for their comments on draft copies of this paper. The study was kindly supported by a grant from the Ministry of Works and Development (Power Division).

\section{REFERENCES}

Brodie, J. W.; Irwin, J. 1970: Morphology and sedimentation in Lake Wakatipu, New Zealand. New Zealand journal of marine and freshwater reseach 4: $479-496$.

Callander, R. A.; Duder, J. N. 1979: Reservoir sedimentation in the Rangitaiki River. New Zealand engineering $34: 208-215$.

Carroll, D. 1970: Clay minerals: a guide to their X-ray identification. Geological Society of America special paper 126.

Chen, Y. H.; Lopez, J. L.; Richardson, E. V. 1978: Mathematical modelling of sediment deposition in reservoirs. American Society of Civil Engineers journal of the Hydraulics Division HY12: $1605-1617$.

Folk, R. L. 1968: Petrology of sedimentary rocks. Austin, Hemphill's.

Folk, R. L.; Andrews, P. B.; Lewis, D. W. 1970: Detrital sedimentary rock classification and nomenclature for use in New Zealand. New Zealand journal of geology and geophysics 13: 937-968.

Gould, H. R. 1960: Turbidity currents and sedimentation in Lake Mead. In: Smith, $W$. $O$. et al. Comprehensive survey of sedimentation in Lake Mead, 1948-49. United States Geological Survey professional paper 295 : $149-186 ; 195-248$.

Green, J. D. 1975: Light penetration. In: Jolly, V. H.; Brown, J. M. A. eds, New Zealand lakes. Auckland, Auckland University Press and Oxford University Press. p. 84-88.

Healy, J. 1964: Dating of the younger volcanic eruptions of the Taupo Region, Part 1. In: Stratigraphy and chronology of Late Quaternary volcanic ash in Taupo, Rotorua, and Gisborne districts. New Zealand Geological Survey bulletin 73: 7-42.

Healy, J.; Schofield, J. C.; Thompson, B. N. 1964: Sheet 5 Rotorua. Geological map of New Zealand 1:250 000. Wellington, New Zealand Department of Scientific and Industrial Research.

Healy, T. R.; Harray, K. G.; Richmond, B. 1977: The Bay of Plenty coastal erosion survey. Occasional report no. 3, University of Waikato, Department of Earth Sciences.
Hopkins, A. C. 1978: Metrication in hydrology. Handbook of hydrological procedures. Procedure no. 45 . Wellington, Water and Soil Division, New Zealand Ministry of Works and Development.

Hutchinson, G. E. 1957: A treatise on limnology. Vol. 1. New York, Wiley.

Jolly, V. H. 1968: The comparative limnology of some New Zealand lakes. Part 1: Physical and chemical. New Zealand joumal of marine and freshwater research $2: 214-259$.

Jordan, C. F.; Fryer, G. E.; Hemmen, E. H. 1971: Size analysis of silt and clay by hydrophotometer. Journal of sedimentary petrology $41: 489-496$.

Kamp, P. J. J. 1979: Computer processing of earth materials data. Occasional report no. 4., University of Waikato, Department of Earth Sciences.

Killworth, P. D.; Carmack, E. C. 1979: A filling-box model of river dominated lakes. Limnology and oceanography $24: 201-217$.

Lambert, A. M.; Lüthi, S. M. 1977: Lake circulation induced by density currents: an experimental approach. Sedimentology $24: 735-741$.

Magadza, C. H. D. 1973: Comparative limnology of six hydroelectric dams on the Waikato River, New Zealand, 1970-72. Unpublished PhD thesis, University of Auckland, Auckland, New Zealand.

Nelson, C. S.; Cochrane, R. H. A. 1970: A rapid X-ray method for the quantitative determination of selected minerals in fine-grained and altered rocks. Tane 16: 151-162.

New Zealand Ministry of Works and Development 1978: Hydrological statistics - power stations and lakes. Wellington, Investigations Section, Power Design Office, Ministry of Works and Development.

Pettijohn, F. J. 1975: Sedimentary rocks (3rd ed.). New York, Harper and Row.

Pharo, C. W.; Carmack, E. C. 1979: Sedimentation processes in a short residence-time intermontane lake, Kamloops Lake, British Columbia. Sedimentology $26: 523-541$.

Phillips, C. J. 1980: Hydrology and sedimentology of an artificial lake - Lake Matahina, New Zealand. Unpublished MSc thesis, University of Waikato, Hamilton, New Zealand.

Pullar, W. A.; Selby, M. J. 1971: Costal progradation of Rangitaiki Plains, New Zealand. New Zealand journal of science $14: 419-434$.

Reineck, H. E.; Singh, I. B. 1973: Depositional sedimentary environments. New York, Springer-Verlag.

Wetzel, R. G. 1975: Limnology. London, Saunders. 